\title{
Pusillimonas ginsengisoli sp. nov., isolated from soil of a ginseng field
}

\author{
Sathiyaraj Srinivasan, ${ }^{1}$ Myung Kyum Kim, ${ }^{1,2}$ Gayathri Sathiyaraj, ${ }^{1}$ \\ Yeon-Ju Kim ${ }^{1}$ and Deok-Chun Yang ${ }^{1}$ \\ ${ }^{1}$ Korean Ginseng Center and Ginseng Genetic Resource Bank, Kyung Hee University, 1 Seocheon- \\ dong, Giheung-gu Yongin-si, Gyeonggi-do 449-701, Republic of Korea \\ ${ }^{2}$ Department of Bio and Environmental Technology, Division of Environmental and Life Science, \\ College of Natural Science, Seoul Women's University, Seoul 139-774, Republic of Korea
}

Correspondence

Deok-Chun Yang

deokchunyang@yahoo.co.kr
Two novel strains of Gram-negative, non-sporulating, short rod-shaped, motile bacteria, designated DCY $25^{\top}$ and DCY28, were isolated from soil of a ginseng field in South Korea and characterized in order to determine their taxonomic position. 16S rRNA gene sequence analysis showed that strains DCY $25^{\top}$ and DCY28 belonged to the Betaproteobacteria, the highest sequence similarities being found with Pusillimonas noertemannii $\mathrm{BN9}^{\top}$ (96.9\%), Bordetella trematum DSM $11334^{\top}$ (95.9\%), Achromobacter denitrificans DSM 30026 ${ }^{\top}(95.9 \%)$, Achromobacter insolitus LMG $6003^{\top}$ (95.8\%) and Pigmentiphaga kullae K24 $4^{\top}(95.5 \%)$. Chemotaxonomic data revealed that both strains $\mathrm{DCY}^{\mathrm{T}} \mathrm{5}^{\mathrm{T}}$ and $\mathrm{DCY} 28$ possessed ubiquinone Q8. Fatty acid analysis of strain DCY $25^{\top}$ demonstrated the presence of $19: 0$ cyclo $\omega 8 c(22.8 \%)$ and $16: 0(16.6 \%)$. The polar lipid profiles of strains DCY $25^{\top}$ and DCY28 included phosphatidylethanolamine, phosphatidylglycerol, two unknown aminolipids and diphosphatidylglycerol. The G $+\mathrm{C}$ contents of strains DCY $25^{\top}$ and DCY28 were 57.3 and $57.2 \mathrm{~mol} \%$, respectively. DNA-DNA relatedness values, biochemical and physiological characteristics strongly supported the genotypic and phenotypic differentiation of strains DCY $25^{\top}$ and DCY28 from Pusillimonas noertemannii. Therefore, strains DCY $25^{\top}$ and DCY 28 should be classified in a novel species, for which the name Pusillimonas ginsengisoli sp. nov. is proposed. The type strain is DCY $25^{\top}\left(=\right.$ KCTC $\left.22046^{\top}=\mathrm{JCM} 14767^{\top}\right)$; strain DCY28 $(=$ KCTC $22047=\mathrm{JCM} 14768)$ is a reference strain.
The family Alcaligenaceae (De Ley et al., 1986) belongs to the order Burkholderiales within the Betaproteobacteria. The genus Pusillimonas was proposed by Stolz et al. (2005) and currently contains only one species with a validly published name, Pusillimonas noertemannii.

During a series of studies to investigate the community structure of micro-organisms in ginseng fields with a culture-dependent method, strains DCY $25^{\mathrm{T}}$ and DCY28 were isolated from surface soil from a ginseng field near Daejeon city in South Korea. A soil sample (1 g) was mixed with $50 \mathrm{ml}$ saline solution, vortexed and serially diluted and an aliquot $(0.1 \mathrm{ml})$ was spread on 1/10 R2A agar (Difco). The plates were incubated at $30{ }^{\circ} \mathrm{C}$ for 3 days and

The GenBank/EMBL/DDBJ accession numbers for the $16 \mathrm{~S}$ rRNA gene sequence of strains DCY25 ${ }^{\top}$ and DCY28 are EF672088 and EF672089, respectively.

A chromatogram of polar lipids of strain $\mathrm{DCY} 25^{\top}$ and a table of DNADNA relatedness values between strains $D C Y 25^{\top}$ and DCY28 and the type strains of type species of closely related genera are available with the online version of this paper. single colonies were purified by repeated subcultivation. Cells of pure cultures were tentatively identified after partial 16S rRNA gene sequencing.

Morphology and motility of cells from 3-day-old colonies grown on $\mathrm{R} 2 \mathrm{~A}$ agar at $30{ }^{\circ} \mathrm{C}$ were observed with a Nikon light microscope (magnification $\times 1000)$. Gram reactions were conducted according to the non-staining method as described by Buck (1982). Oxidase activity was tested by oxidation of $1 \% p$-aminodimethylaniline oxalate. Catalase activity was tested by bubble production from $3 \%(\mathrm{v} / \mathrm{v})$ hydrogen peroxide solution (Cappuccino \& Sherman, 2002). Growth at $4,15,18,25,30,37$ and $42{ }^{\circ} \mathrm{C}$ and $\mathrm{pH}$ 5.0-10.0, at intervals of $0.5 \mathrm{pH}$ units, was assessed in R2A broth. Anaerobic growth was tested in serum bottles containing $1 \mathrm{~g}$ thioglycolate $\mathrm{l}^{-1}$ in R2A broth and nitrogen gas as the gaseous layer. The API 20NE, API 50CH, API ZYM and API ID 32GN systems (bioMérieux) were used according to the manufacturer's instructions.

Isoprenoid quinones were extracted with chloroform/ methanol $(2: 1, \mathrm{v} / \mathrm{v})$, purified with TLC and analysed by 
HPLC as described by Collins \& Jones (1981) and Shin et al. (1996). To determine the cellular fatty acids, each strain was grown on TSA (Difco) for $48 \mathrm{~h}$ at $30{ }^{\circ} \mathrm{C}$ and two loopfuls of cell material were then harvested and fatty acid methyl esters were prepared, separated and identified with the Sherlock Microbial Identification System (Sasser, 1990). Polar lipids were extracted and examined by twodimensional TLC (Minnikin et al., 1977).

For the determination of the DNA G $+\mathrm{C}$ content, genomic DNA was extracted and purified with the Qiagen Genomictip system 100/G (Qiagen) and degraded enzymically into nucleosides. The nucleosides were analysed using HPLC as described by Tamaoka \& Komagata (1984) and Mesbah et al. (1989). DNA-DNA hybridization was performed fluorometrically, according to the method developed by Ezaki et al. (1989), using photobiotin-labelled DNA probes and micro-dilution wells. For each sample, five replicate hybridizations were conducted, the highest and lowest values were excluded and the DNA-DNA relatedness value was calculated as the mean of the remaining three values.

The 16S rRNA gene was amplified from chromosomal DNA using the universal bacterial primer set $\mathrm{fD} 1$ and $\mathrm{rP} 1$ (Weisburg et al., 1991). Purified PCR products were sequenced by Genotec (Daejeon, Korea; Kim et al., 2005) and the sequences were compiled with SeqMan software (DNASTAR Inc). 16S rRNA gene sequences of related taxa were obtained from GenBank and edited using the BioEdit program (Hall, 1999). Multiple alignments were performed with CLUSTAL X (Thompson et al., 1997). Evolutionary distances were calculated using Kimura's two-parameter model (Kimura, 1983). A phylogenetic tree was constructed with the neighbour-joining method (Saitou \& Nei, 1987) in MEGA3 (Kumar et al., 2004). Bootstrap analysis with 1000 replicates was conducted in order to obtain confidence levels for the branch nodes (Felsenstein, 1985).

After growth on R2A agar at $30{ }^{\circ} \mathrm{C}$ for 5 days, colonies of strains DCY $25^{\mathrm{T}}$ and DCY 28 were pale yellow and circular. Cells were aerobic, Gram-negative, motile coccobacilli and grew optimally at $30{ }^{\circ} \mathrm{C}$. The physiological characteristics of strains DCY $25^{\mathrm{T}}$ and DCY28 are given in the species description and in Table 1.

The cellular fatty acids in strain DCY $25^{\mathrm{T}}$ were 19:0 cyclo $\omega 8 c(22.8 \%), 16: 0(16.6 \%)$, summed feature 2 (iso-16: 1 I and/or 14:0 3-OH; 15.3\%), 17:0 cyclo (8.7\%), summed feature $3(16: 1 \omega 6 c$ and/or $16: 1 \omega 7 c ; 8.6 \%)$, summed feature $8(18: 1 \omega 7 c$ and/or $18: 1 \omega 6 c ; 7.0 \%), 14: 0(6.4 \%)$ and 18:0 (6.2\%). Table 2 shows the fatty acid profiles of strains DCY $25^{\mathrm{T}}$ and DCY28 and the type strains of the type species of closely related genera. The major fatty acids of strains DCY25 ${ }^{\mathrm{T}}$ and DCY28 were similar to those of Pusillimonas noertemannii DSM $10065^{\mathrm{T}}$ but differed in quantities. The predominant quinone of strains DCY $25^{\mathrm{T}}$ and DCY28 was Q-8, which supported our assignment of the strains to the order Burkholderiales, in which the majority of species, including Pusillimonas noertemannii,
Table 1. Differential characteristics between strains DCY $25^{\top}$ and DCY28 and the type strains of the type species of closely related genera

Strains: 1, Pusillimonas ginsengisoli sp. nov. DCY $25^{\mathrm{T}} ; 2$, Pusillimonas ginsengisoli sp. nov. DCY28; 3, Pusillimonas noertemannii DSM $10065^{\mathrm{T}} ; 4$, Achromobacter xylosoxidans DSM $10346^{\mathrm{T}} ; 5$, Bordetella pertussis DSM $5571^{\mathrm{T}} ; 6$, Pigmentiphaga kullae DSM $13608^{\mathrm{T}}$. Data were obtained in this study unless indicated otherwise. +, Positive; w, weakly positive; - , negative.

\begin{tabular}{|c|c|c|c|c|c|c|}
\hline Characteristic & 1 & 2 & 3 & 4 & 5 & 6 \\
\hline $\begin{array}{l}\text { Colony colour } \\
(\text { LB agar })^{*}\end{array}$ & PY & PY & B & PW & WC & WC \\
\hline \multicolumn{7}{|l|}{ Cell dimensions } \\
\hline Length $(\mu \mathrm{m})$ & $\begin{array}{r}0.5- \\
0.8\end{array}$ & $\begin{array}{r}0.5- \\
0.8\end{array}$ & $\begin{array}{l}1- \\
1.5^{a_{\dagger}}\end{array}$ & $\begin{array}{l}2.5- \\
3.0^{b}\end{array}$ & $\begin{array}{l}1.0- \\
2.8^{c}\end{array}$ & $\begin{array}{r}1.3- \\
4^{d}\end{array}$ \\
\hline Width $(\mu \mathrm{m})$ & $\begin{array}{r}0.3- \\
0.6\end{array}$ & $\begin{array}{r}0.4- \\
0.7\end{array}$ & $\begin{array}{c}0.5- \\
0.5^{a}\end{array}$ & $\begin{array}{c}0.8^{-} \\
1.2^{b}\end{array}$ & $\begin{array}{r}0.4- \\
0.7^{c}\end{array}$ & $\begin{array}{c}0.7- \\
1.2^{d}\end{array}$ \\
\hline \multicolumn{7}{|l|}{ Production of: } \\
\hline Nitrite from nitrate & + & + & - & + & - & - \\
\hline Acid from glucose & - & - & - & - & $\mathrm{W}$ & + \\
\hline \multicolumn{7}{|l|}{$\begin{array}{l}\text { Enzyme activity } \\
\text { (API ZYM) }\end{array}$} \\
\hline $\begin{array}{l}N \text {-Acetyl- } \beta \text { - } \\
\text { glucosaminidase }\end{array}$ & - & - & + & - & - & - \\
\hline Acid phosphatase & + & + & - & + & - & + \\
\hline$\alpha$-Chymotrypsin & + & + & - & - & - & + \\
\hline Cystine arylamidase & + & + & - & - & - & - \\
\hline$\alpha$-Galactosidase & - & - & + & - & - & - \\
\hline $\begin{array}{l}\alpha \text {-Glucosidase } \\
\quad \text { (starch hydrolysis) }\end{array}$ & - & - & + & - & - & - \\
\hline Leucine arylamidase & + & + & - & $\mathrm{W}$ & $\mathrm{W}$ & + \\
\hline $\begin{array}{l}\text { Naphthol-AS-BI- } \\
\text { phosphohydrolase }\end{array}$ & + & + & - & + & + & + \\
\hline Trypsin & + & + & - & - & - & + \\
\hline Urease & - & - & + & - & + & + \\
\hline \multicolumn{7}{|l|}{$\begin{array}{l}\text { Assimilation } \\
\text { (API ID 32GN, API } \\
\text { 20NE) of: }\end{array}$} \\
\hline 3-Hydroxybenzoate & - & - & + & - & + & + \\
\hline 4-Hydroxybenzoate & - & - & + & - & + & + \\
\hline Adipate & + & + & - & + & - & + \\
\hline Caprate & - & - & + & + & $\mathrm{w}$ & - \\
\hline Citrate & + & + & - & + & - & + \\
\hline Malonate & + & - & - & - & - & - \\
\hline Phenyl acetate & + & + & - & + & - & + \\
\hline Propionate & + & + & - & $\mathrm{w}$ & $\mathrm{w}$ & + \\
\hline Suberate & - & - & + & + & + & $\mathrm{w}$ \\
\hline n-Valerate & + & + & $\mathrm{w}$ & $\mathrm{w}$ & $\mathrm{w}$ & + \\
\hline D-Glucose & - & - & + & + & + & - \\
\hline D-Ribose & - & + & - & - & - & - \\
\hline myo-Inositol & - & - & + & $\mathrm{w}$ & $\mathrm{w}$ & - \\
\hline L-Alanine & + & + & - & - & - & - \\
\hline $\begin{array}{l}\text { DNA G + C content } \\
(\mathrm{mol} \%)\end{array}$ & 57.3 & 57.2 & $61.8^{a}$ & $65-70^{b}$ & $63.8^{c}$ & $68.5^{d}$ \\
\hline
\end{tabular}

${ }^{\star} \mathrm{B}$, Brownish; PW, pale white; PY, pale yellow; wC, white cream. $\dagger$ Data taken from: $a$, Stolz et al. (2005); b, Yabuuchi \& Yano (1981); c, von Wintzingerode et al. (2001); d, Blümel et al. (2001). 
Table 2. Cellular fatty acid profiles of strains $D C Y 25^{\top}$ and DCY28 and the type strains of the type species of closely related genera

Strains: 1, Pusillimonas ginsengisoli sp. nov. DCY $25^{\mathrm{T}} ; 2$, Pusillimonas ginsengisoli sp. nov. DCY28; 3, Pusillimonas noertemannii DSM $10065^{\mathrm{T}}$; 4, Achromobacter xylosoxidans DSM $10346^{\mathrm{T}}$; 5, Bordetella pertussis DSM $5571^{\mathrm{T}} ; 6$, Pigmentiphaga kullae DSM $13608^{\mathrm{T}}$. Data were taken from this study after culture on TSA agar at $30{ }^{\circ} \mathrm{C}$ for $48 \mathrm{~h}$. tr, $<1.0 \%$ of the total; - , not detected.

\begin{tabular}{|c|c|c|c|c|c|c|}
\hline Fatty acid (\%) & 1 & 2 & 3 & 4 & 5 & 6 \\
\hline \multicolumn{7}{|l|}{ Saturated } \\
\hline $10: 03-\mathrm{OH}$ & - & - & - & $\operatorname{tr}$ & $\operatorname{tr}$ & 1.6 \\
\hline $12: 0$ & $\operatorname{tr}$ & $\operatorname{tr}$ & 6.7 & 4.8 & 3.4 & - \\
\hline $12: 02-\mathrm{OH}$ & - & - & 4.6 & 2.0 & 3.2 & - \\
\hline $14: 0$ & 6.4 & 7.9 & 1.5 & 4.7 & $\operatorname{tr}$ & $\operatorname{tr}$ \\
\hline $14: 02-\mathrm{OH}$ & - & - & - & 2.1 & 1.5 & 2.4 \\
\hline $16: 0$ & 16.6 & 17.3 & 14.2 & 27.4 & 19.8 & 30.5 \\
\hline $16: 02-\mathrm{OH}$ & - & - & - & $\operatorname{tr}$ & $\operatorname{tr}$ & 2.6 \\
\hline $16: 03-\mathrm{OH}$ & - & - & 1.6 & $\operatorname{tr}$ & 1.3 & $\operatorname{tr}$ \\
\hline $17: 0$ & 2.6 & 3.1 & $\operatorname{tr}$ & $\operatorname{tr}$ & - & - \\
\hline $17: 0$ cyclo & 8.7 & 5.4 & 24.9 & 10.0 & 16.8 & 25.2 \\
\hline $18: 0$ & 6.2 & 5.6 & 1.9 & $\operatorname{tr}$ & 4.3 & 1.1 \\
\hline 18:0 10-methyl & - & - & - & - & 8.9 & - \\
\hline $19: 0$ cyclo $\omega 8 c$ & 22.8 & 23.2 & 14.5 & 0.3 & 17.5 & 14.9 \\
\hline \multicolumn{7}{|l|}{ Unsaturated } \\
\hline $13: 1$ at $12-13$ & $\operatorname{tr}$ & $\operatorname{tr}$ & 2.6 & $\operatorname{tr}$ & $\operatorname{tr}$ & - \\
\hline $15: 1 \omega 8 c$ & $\operatorname{tr}$ & $\operatorname{tr}$ & $\operatorname{tr}$ & - & $\operatorname{tr}$ & - \\
\hline $18: 1 \omega 7 c$ & 3.7 & 4.1 & 2.1 & - & - & 10.9 \\
\hline $18: 1 \omega 9 c$ & - & - & - & $\operatorname{tr}$ & 3.9 & 1.3 \\
\hline $18: 12-\mathrm{OH}$ & - & - & 1.6 & - & 2.8 & 1.8 \\
\hline \multicolumn{7}{|l|}{ Summed features* } \\
\hline 2 & 15.3 & 12.9 & 9.5 & 13.6 & 5.6 & 3.9 \\
\hline 3 & 8.6 & 10.4 & 9.8 & 24.8 & 7.4 & 1.8 \\
\hline 8 & 7.0 & 8.3 & 2.4 & 6.9 & $\operatorname{tr}$ & $\operatorname{tr}$ \\
\hline
\end{tabular}

${ }^{*}$ Summed features represent two or three fatty acids that cannot be separated by the Microbial Identification System. Summed feature 2 consisted of iso-16:1 I and/or 14:0 3-OH. Summed feature 3 consisted of $16: 1 \omega 6 c$ and/or $16: 1 \omega 7 c$. Summed feature 8 consisted of $18: 1 \omega 7 c$ and/or $18: 1 \omega 6 c$.

exhibit Q-8 as the predominant quinone. The polar lipid compositions of strains DCY $25^{\mathrm{T}}$ and DCY 28 were very similar and included phosphatidylethanolamine and phosphatidylglycerol as the predominant lipids, moderate amounts of two unknown aminolipids and diphosphatidylglycerol and minor amounts of an unknown aminophospholipid and two unknown lipids (Supplementary Fig. S1, available in IJSEM Online). The polar lipid profile was similar to that of Pusillimonas noertemannii DSM $10065^{\mathrm{T}}$, albeit with different quantities.

The $16 \mathrm{~S}$ rRNA gene sequences of strains DCY $25^{\mathrm{T}}$ and DCY 28 obtained in this study were continuous stretches of 1479 and 1434 nucleotides, respectively. Comparisons with $16 \mathrm{~S}$ rRNA gene sequences of related taxa suggested that strains DCY $25^{\mathrm{T}}$ and DCY28 belong to the Betaproteobacteria, order Burkholderiales, family Alcaligenaceae. High sequence similarities were found between strain DCY $25^{\mathrm{T}}$ and strain DCY28 (99.6\%), Pusillimonas noertemannii $\mathrm{BN}^{\mathrm{T}}$ (96.9\%), Bordetella trematum DSM $11334^{\mathrm{T}}$ (95.9\%), Achromobacter denitrificans DSM $30026^{\mathrm{T}}$ (95.9\%), Achromobacter insolitus LMG $6003^{\mathrm{T}}(95.8 \%)$ and Pigmentiphaga kullae $\mathrm{K} 24^{\mathrm{T}}$ $(95.5 \%)$. The phylogenetic tree (Fig. 1) clearly shows that strains DCY $25^{\mathrm{T}}$ and DCY28 belong to the Pusillimonas lineage.

The genomic DNA G + C contents of strains DCY $25^{\mathrm{T}}$ and DCY28 were 57.3 and $57.2 \mathrm{~mol} \%$, respectively. Strain DCY $25^{\mathrm{T}}$ exhibited a high level of DNA-DNA relatedness with strain DCY28 (87\%) and a low level with Pusillimonas noertemannii DSM $10065^{\mathrm{T}}(20 \%)$. Other DNA-DNA relatedness values are given in Supplementary Table S1.

Thus, the results of our polyphasic analysis support the placement of strains DCY $25^{\mathrm{T}}$ and DCY 28 in a separate and previously unrecognized species within the genus Pusillimonas, for which the name Pusillimonas ginsengisoli sp. nov. is proposed.

\section{Description of Pusillimonas ginsengisoli. sp. nov.}

Pusillimonas ginsengisoli (gin.sen.gi.so'li. N.L. n. ginsengum ginseng; L. n. solum -i soil; N.L. gen. n. ginsengisoli of soil of a ginseng field, the source of the type strain).

Cells are Gram-negative, aerobic, motile, short rods, 0.5$0.8 \mu \mathrm{m}$ long and $0.3-0.6 \mu \mathrm{m}$ in diameter. Colonies are pale yellow and circular with an entire margin after growth on nutrient agar at $30{ }^{\circ} \mathrm{C}$ for 5 days. Grows at $15-40{ }^{\circ} \mathrm{C}$ (optimum $30{ }^{\circ} \mathrm{C}$ ), but not at 4 or $42{ }^{\circ} \mathrm{C}$, and at pH 5.5-9.0 (optimum pH 7.0). Oxidase- and catalase-positive. Produces acid phosphatase, alkaline phosphatase, $\alpha$-chymotrypsin, cystine arylamidase, esterase (C4), esterase (C8), leucine arylamidase, naphthol-AS-BI-phosphohydrolase, trypsin and valine arylamidase. Does not produce $N$-acetyl- $\beta$-glucosaminidase, arginine dihydrolase, $\alpha$-fucosidase, $\beta$-galactosidase (PNPG hydrolysis), $\alpha$-galactosidase, $\alpha$-glucosidase (starch hydrolysis), $\beta$-glucosidase (aesculin hydrolysis), $\beta$-glucuronidase, lipase (C14), $\alpha$-mannosidase, protease (gelatin hydrolysis) or urease. Assimilates acetate, adipate, L-alanine, citrate, 3-hydroxybutyrate, itaconate, DL-lactate, L-malate, phenylacetate, $\mathrm{L}$-proline, propionate, $\mathrm{L}$-serine and $\mathrm{n}$-valerate. Does not assimilate $\mathrm{N}$-acetyl-D-glucosamine, L-arabinose, caprate, L-fucose, gluconate, D-glucose, glycogen, L-histidine, 3-hydroxybenzoate, 4-hydroxybenzoate, 2-ketogluconate, 5-ketogluconate, maltose, D-mannitol, D-mannose, melibiose, myo-inositol, L-rhamnose, salicin, D-sorbitol, suberate or sucrose. The predominant quinone is Q-8. The major fatty acids $(>5 \%)$ are 19:0 cyclo $\omega 8 c, 16: 0$, summed feature 2 (iso-16: $1 \mathrm{I}$ and/or 14:0 3-OH), 17:0 cyclo, summed feature $3(16: 1 \omega 6 c$ and/or $16: 1 \omega 7 c)$, summed feature $8(18: 1 \omega 7 c$ and/or $18: 1 \omega 6 c), 14: 0$ and $18: 0$. The predominant polar lipids are phosphatidylethanolamine and phosphatidylglycerol; moderate amounts of unknown aminolipids and 


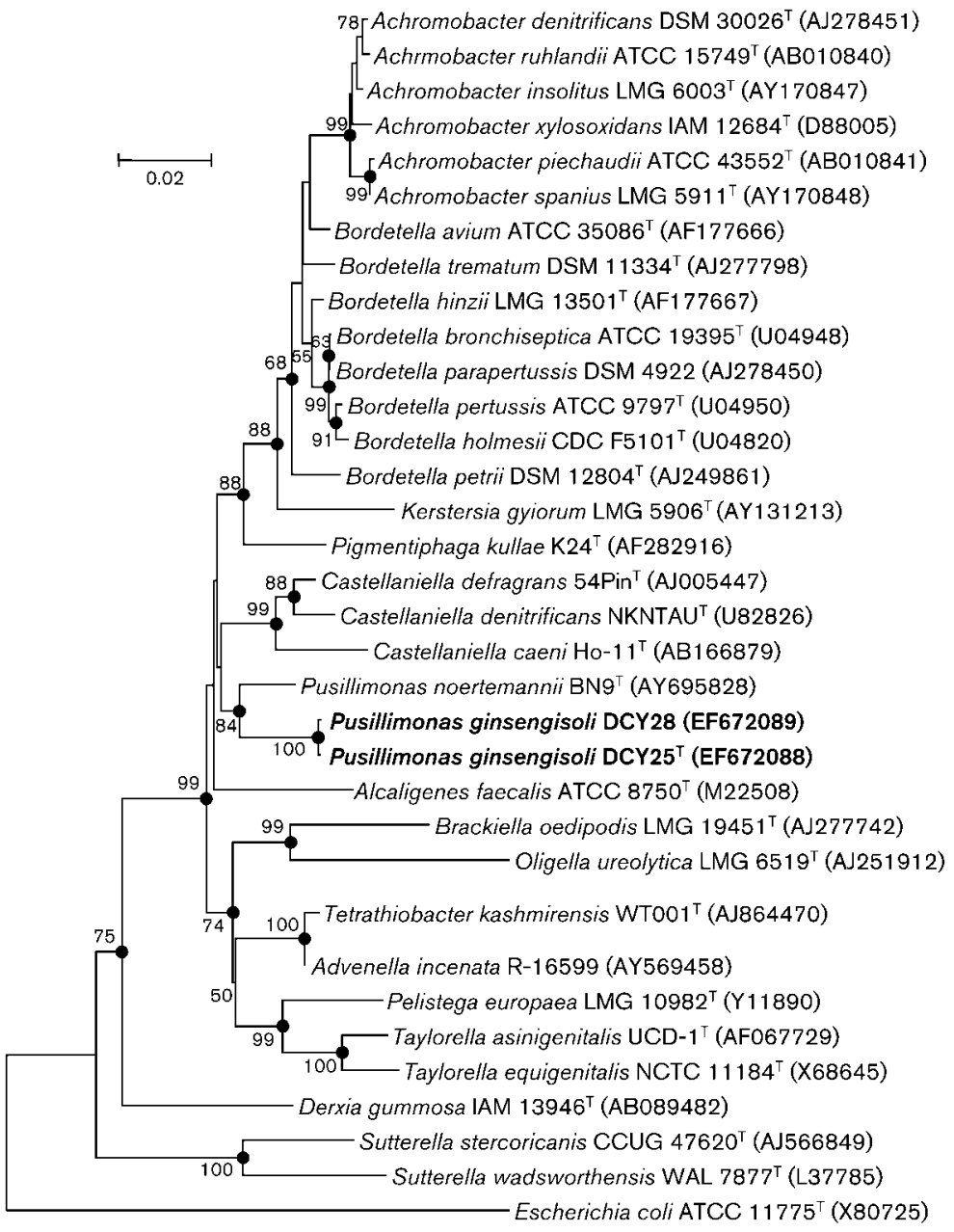

Fig. 1. Neighbour-joining phylogenetic tree showing the relationships between strains DCY $25^{\top}$ and DCY28 and related strains. Bootstrap values $(>50 \%)$ based on 1000 replications are shown as percentages at branch nodes. Filled circles indicate that the corresponding nodes were also recovered in trees generated with the maximum-parsimony algorithm. Bar, 0.02 substitutions per nucleotide position. diphosphatidylglycerol and minor amounts of unknown aminophospholipids and lipids are also found. The $\mathrm{G}+\mathrm{C}$ content of the type strain is $57.3 \mathrm{~mol} \%$ (HPLC).

The type strain, DCY $25^{\mathrm{T}}\left(=\right.$ KCTC $\left.22046^{\mathrm{T}}=\mathrm{JCM} 14767^{\mathrm{T}}\right)$, and strain DCY28 (=KCTC $22047=\mathrm{JCM} 14768)$ were isolated from soil of a ginseng field near Daejeon city, in South Korea.

\section{Acknowledgements}

This study was supported by KGCMVP for Technology Development Program of Agriculture and Forestry, Ministry of Agriculture and Forestry, Republic of Korea.

\section{References}

Blümel, S., Mark, B., Busse, H.-J., Kämpfer, P. \& Stolz, A. (2001). Pigmentiphaga kullae gen. nov., sp. nov., a novel member of the family Alcaligenaceae with the ability to decolorize azo dyes aerobically. Int $J$ Syst Evol Microbiol 51, 1867-1871.

Buck, J. D. (1982). Nonstaining (KOH) method for determination of Gram reactions of marine bacteria. Appl Environ Microbiol 44, 992-993.

Cappuccino, J. G. \& Sherman, N. (2002). Microbiology: a Laboratory Manual, 6th edn. Menlo Park, CA: Benjamin/Cummings.
Collins, M. D. \& Jones, D. (1981). Distribution of isoprenoid quinone structural types in bacteria and their taxonomic implications. Microbiol Rev 45, 316-354.

De Ley, J., Segers, P., Kersters, K., Mannheim, W. \& Lievens, A. (1986). Intra- and intergeneric similarities of the Bordetella ribosomal ribonucleic acid cistrons: proposal for a new family, Alcaligenaceae. Int J Syst Bacteriol 36, 405-414.

Ezaki, T., Hashimoto, Y. \& Yabuuchi, E. (1989). Fluorometric deoxyribonucleic acid-deoxyribonucleic acid hybridization in microdilution wells as an alternative to membrane filter hybridization in which radioisotopes are used to determine genetic relatedness among bacterial strains. Int J Syst Bacteriol 39, 224-229.

Felsenstein, J. (1985). Confidence limits on phylogenies: an approach using the bootstrap. Evolution 39, 783-791.

Hall, T. A. (1999). BioEdit: a user-friendly biological sequence alignment editor and analysis program for Windows 95/98/NT. Nucleic Acids Symp Ser 41, 95-98.

Kim, M. K., Im, W.-T., Ohta, H., Lee, M. \& Lee, S.-T. (2005). Sphingopyxis granuli sp. nov., a beta-glucosidase-producing bacterium in the family Sphingomonadaceae in alpha-4 subclass of the Proteobacteria. J Microbiol 43, 152-157.

Kimura, M. (1983). The Neutral Theory of Molecular Evolution. Cambridge: Cambridge University Press.

Kumar, S., Tamura, K. \& Nei, M. (2004). MEGA3: integrated software for molecular evolutionary genetics analysis and sequence alignment. Brief Bioinform 5, 150-163. 
Mesbah, M., Premachandran, U. \& Whitman, W. B. (1989). Precise measurement of the $\mathrm{G}+\mathrm{C}$ content of deoxyribonucleic acid by highperformance liquid chromatography. Int J Syst Bacteriol 39, 159-167.

Minnikin, D. E., Patel, P. V., Alshamaony, L. \& Goodfellow, M. (1977). Polar lipid composition in the classification of Nocardia and related bacteria. Int J Syst Bacteriol 27, 104-117.

Saitou, N. \& Nei, M. (1987). The neighbor-joining method: a new method for reconstructing phylogenetic trees. Mol Biol Evol 4, 406-425.

Sasser, M. (1990). Identification of bacteria by gas chromatography of cellular fatty acids, MIDI Technical Note 101. Newark, DE: MIDI Inc.

Shin, Y. K., Lee, J.-S., Chun, C. O., Kim, H.-J. \& Park, Y.-H. (1996). Isoprenoid quinone profiles of the Leclercia adecarboxylata KCTC $1036^{\mathrm{T}}$. J Microbiol Biotechnol 6, 68-69.

Stolz, A., Bürger, S., Kuhm, A., Kämpfer, P. \& Busse, H.-J. (2005). Pusillimonas noertemannii gen. nov., sp. nov., a new member of the family Alcaligenaceae that degrades substituted salicylates. Int J Syst Evol Microbiol 55, 1077-1081.
Tamaoka, J. \& Komagata, K. (1984). Determination of DNA base composition by reversed-phase high-performance liquid chromatography. FEMS Microbiol Lett 25, 125-128.

Thompson, J. D., Gibson, T. J., Plewniak, F., Jeanmougin, F. \& Higgins, D. G. (1997). The CLUSTAL_X windows interface: flexible strategies for multiple sequence alignment aided by quality analysis tools. Nucleic Acids Res 25, 4876-4882.

von Wintzingerode, F., Schattke, A., Siddiqui, R. A., Rösick, U., Göbel, U. B. \& Gross, R. (2001). Bordetella petrii sp. nov., isolated from an anaerobic bioreactor, and emended description of the genus Bordetella. Int J Syst Evol Microbiol 51, 1257-1265.

Weisburg, W. G., Barns, S. M., Pelletier, D. A. \& Lane, D. J. (1991). 16 S ribosomal DNA amplification for phylogenetic study. J Bacteriol 173, 697-703.

Yabuuchi, E. \& Yano, I. (1981). Achromobacter gen. nov. and Achromobacter xylosoxidans (ex Yabuuchi and Ohyama 1971) nom. rev. Int J Syst Bacteriol 31, 477-478. 